\title{
Effects of Governance on Growth in the Central Africa Economic and Monetary Community (CAEMC)
}

\author{
Cyriaque Mbingui, Fernand Owonda, Nellia Elsia Minkala Tsinkonda \\ Laboratory of Research and Economic and Social Studies, Faculty of Economic Sciences of the Marien Ngouabi University, \\ Brazzaville, Republic of Congo \\ Email: mbinguic@gmail.com,owondafernand@yahoo.fr, elsiaminkala@gmail.com
}

How to cite this paper: Mbingui, C., Owonda, F., \& Minkala Tsinkonda, N. E. (2021). Effects of Governance on Growth in the Central Africa Economic and Monetary Community (CAEMC). Open Journal of Social Sciences, 9, 22-41.

https://doi.org/10.4236/jss.2021.97003

Received: May 26, 2021

Accepted: July 9, 2021

Published: July 12, 2021

Copyright () 2021 by author(s) and Scientific Research Publishing Inc. This work is licensed under the Creative Commons Attribution International License (CC BY 4.0).

http://creativecommons.org/licenses/by/4.0/ (c) (i) Open Access

\begin{abstract}
The purpose of this study is to highlight the effects of governance indicators on the growth of CAEMC countries' economies. The analysis conducted using panel data econometrics, in accordance with the generalized method of moments, over a period from 2002 to 2015, showed that corruption, bureaucratic quality and political instability negatively influence the growth of CAEMC countries' economies. In contrast, regulatory quality, rule of law, and citizen voice and accountability had a positive impact on the growth of CAEMC economies. These results have given rise to economic policy implications.
\end{abstract}

\section{Keywords}

Governance, Economic Growth, CAEMC, MMG

\section{Introduction}

Economic growth has become one of the most concerning issues since some studies have shown the impact of governance structures and institutions on the economies of developing countries (Ouhirra \& Sabri, 2019). Kuznets (1973) argues that economic growth improves people's standard of living once it promotes the production of goods and services, and therefore contributes to development and poverty reduction.

Several studies (Solow, 1956; Lucas, 1988; Barro, 1990; ...) have used factors such as technical progress, human capital and investment in physical capital to improve economic growth. But these do not explain the disparities in growth between nations. Some studies have focused on institutional variables to account for output gaps between countries that are not explained by economic variables 
alone. Governance is defined as the way in which the people and affairs of a state are governed and managed and regulated, respectively (ADB, 1999).

Indeed, the relationship between governance and economic growth has been the subject of theoretical debates between proponents of New Institutional Economics (North, 1990; Hall \& Jones, 1999...) and those of classical economics (Buchanan \& Tullock, 1962; Krueger, 1974; Stigler, 1975...). The proponents of the new institutional economics assert that institutions are one of the determining factors of long-term economic growth, while those of classical economics stipulate that the behavior of the state constitutes a brake on economic growth.

The empirical literature also identifies a controversial trend. The work of Kaufmann et al. (2004); Acemoglu et al. $(2015,2019)$ found that the quality of governance has a positive and significant impact on economic growth, is in contrast to Baliamoune-Lutz and Ndikumana (2009); Knack and Keefer (1997); Mo (2001) who showed that poor governance, through political instability and corruption, is a drag on economic growth.

It follows from the above that maintaining a sustainable level of economic growth in the medium and long term requires, theoretically and/or empirically, a qualitative change in governance structures and institutions, as well as in the behavior of actors. Thus, several studies have examined the case of CAEMC, but most of them have focused on only one category of governance indicators (corruption, democracy, rule of law, etc.). In contrast, this study analyzes the relationship of governance, through six (06) narrow indicators, on growth in CAEMC countries. The choice of CAEMC is justified by the fact that some member countries still have serious governance problems (Bangui, 2015). Endowed with abundant natural resources, CAEMC continues to suffer from problems of underdevelopment. According to the FMI (2017), in 2013, 2015, and 2016, CAEMC recorded economic growth (in real GDP) of 2.7\%, 2.1\%, and -0.7 , respectively, compared to the WAEMU $(6.6 \%, 6.2 \%$, and $6.1 \%)$ and Sub-Saharan Africa (5.3\%, 3.4\%, and 1.4\%). In addition, CAEMC has much lower levels of governance indicators than other sub regions. These indicators are: quality of the regulatory framework; control of corruption; and others. According to the FMI (2015), CAEMC is ranked in the bottom 28 percent of the global governance indicator, and only made progress in 50 percent of its governance indicators between 1996 and 2013. In contrast, Africa's pre-emerging economies rank much higher (in the 43 percent range) and have improved 100 percent of their indicators.

The growth situation of African countries suggests that we should question the relevance of the relationship between governance and economic growth. The low level of growth in CAEMC countries in this relationship raises a key question: what are the effects of governance on economic growth in CAEMC member countries? The answer to this question highlights the effects of governance indicators on economic growth in CAEMC member countries. Given the low percentage of governance indicators in the sub-region, this work argues that the quality of governance is a factor in economic growth. 
The remainder of this paper, in addition to the conclusion, is structured around three (3) points which are: 1) the situation of governance and economic growth in CAEMC; 2) governance and economic growth in the literature; and 3) the methodological approach and interpretation of results.

\section{Situation of Governance and Economic Growth in CAEMC}

We present the respective situations of governance and economic growth.

\subsection{Governance}

The slow growth of GDP is explained by the many governance problems that the development of CAEMC countries still faces. According to Bodjongo (2012), institutional underdevelopment in CAEMC countries is characterized by: an increased presence of the practice of corruption in the public and private spheres; political instability characterized by numerous coups d'état, civil wars; inefficiency of government actions marked by the incompetence of some officials; poor quality of public services, "advanced" bureaucracy; non-credibility of the commitments of public decision-makers and dependence on political pressures; a lack of expression and accountability of citizens as evidenced by the absence of freedom of the press and the lack of respect for civil liberties and political rights; a poorer regulatory framework marked by inadequate supervision of financial activities; lack of respect for competition laws; and a weak rule of law index.

Citizens do not trust or respect the laws that govern society. Empirical studies suggest that poor governance is likely to penalize productivity. In the case of CAEMC, weak governance indicators and lack of improvement in governance would have had the same effect. Figure 1 shows the evolution of governance indicators in CAEMC countries.

The reading of this Figure 1 shows that the score of the voice accountability indicator is between -2.4 and -0.4 . For this indicator, the country with the lowest score is Gabon, while the other countries with lower scores are Chad, Central African Republic, Congo, Cameroon and Equatorial Guinea.

The score for the Rule of Law indicator ranges from -2.0 to 0.0 . Equatorial Guinea has the lowest score on this governance indicator.

The score for the Regulatory quality indicator ranges from -1.6 to 0.0 . This indicator is rated less poorly in Congo and Gabon compared to Equatorial Guinea, Cameroon, Chad and the Central African Republic.

The political stability indicator fluctuates between -2.5 and 0.5 . This is the only indicator that has improved in Congo, Equatorial Guinea and Gabon.

The Government Effectiveness indicator score ranges from -2.0 to -0.4 . This indicator is worse in Congo, Gabon and Chad than in Cameroon and Equatorial Guinea.

The corruption indicator, which ranges from -2.0 to -0.4 , shows that corruption is more intense in Congo and Gabon than in the Central African Republic, Chad, Cameroon and Equatorial Guinea. 
VOICE_ACCOUNT

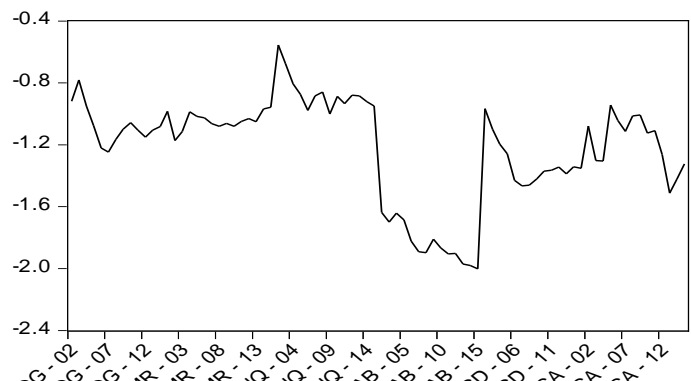

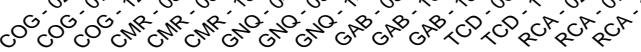

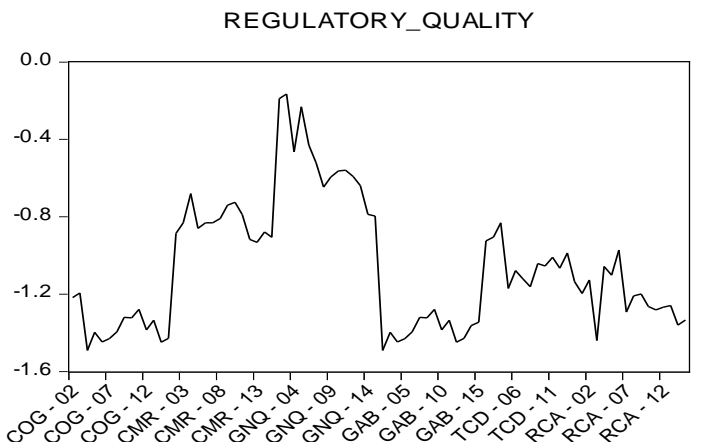

GOV_EFFECTI

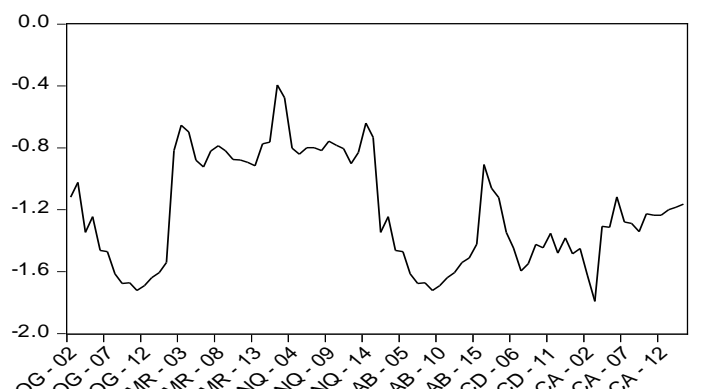

RULE_LAW

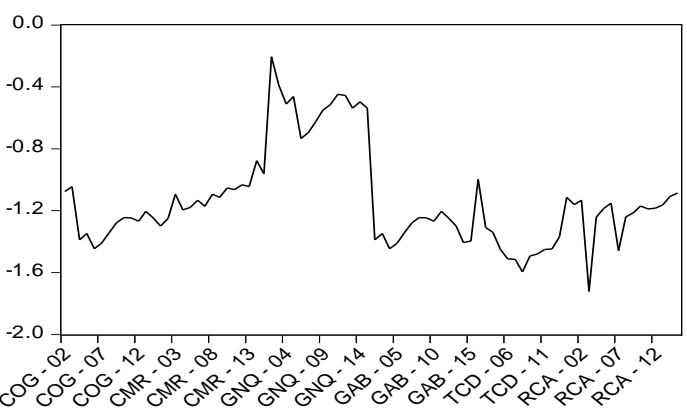

Political instability and Violence/Terrorism

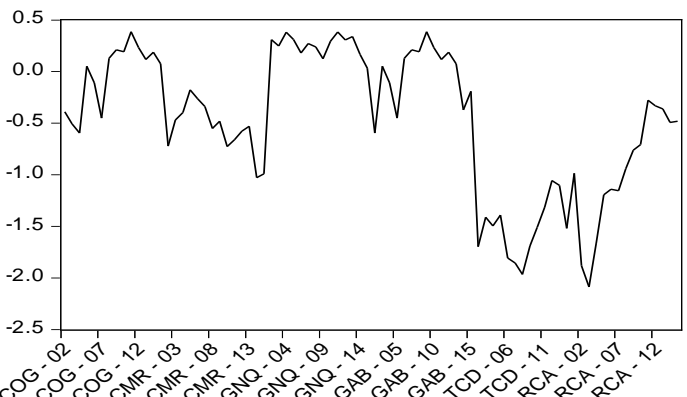

CORRUPT

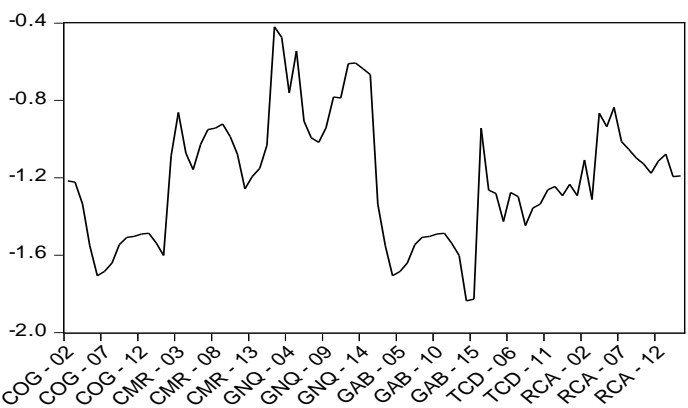

Figure 1. Evolution of governance indicators in CAEMC countries. Source: authors, using data from the World Bank (WDI, 2018).

In general, among the governance indicators for the CEMAC economies, which range from -2.5 to 0.5 , only the political stability indicator improved in Congo, Equatorial Guinea, and Gabon. The scores for the other indicators (government effectiveness, regulatory quality, voice accountability, rule of law, and corruption), which were rated poorly, fluctuated between -2.5 and 0.00 .

\subsection{Economic Growth}

According to the FMI (2015), GDP growth in CAEMC has been slower compared to other sub-regions in Sub-Saharan Africa. While average income has increased significantly in the pre-emerging countries of Sub-Saharan Africa and in Asian countries, average income in CAEMC has grown only modestly since the early 2000s. The latter recorded real GDP growth of only $2.7 \%$ in $2013 ; 2.1 \%$ in 2015 and -0.7 in 2016 compared to $6.6 \% ; 6.2 \%$ and $6.1 \%$ for the WAEMU and 
5.3\%; 3.4\% and $1.4 \%$ for Sub-Saharan Africa as a whole (FMI, 2017). The following Figure 2 shows the cross-sectional evolution of real GDP growth in Sub-Saharan Africa, the CAEMC and the WAEMU.

In addition, a country-by-country decomposition shows that the high average GDP growth in the CAEMC is largely attributable to the oil boom in Equatorial Guinea, which began in the mid-1990s. The CAEMC converged toward the average income level of emerging economies in Sub-Saharan Africa from the mid-1990s to the mid-2000s, during which time its average GDP grew faster than in emerging economies. However, since 2005, and despite high oil prices until recently, convergence has stalled.

As a result, the income gap with the emerging economies of Sub-Saharan Africa has remained at about 30 percent. At the same time, the lower-income but faster growing pre-emerging economies of Sub-Saharan Africa have been catching up. From 2000 to 2013, average GDP growth in the CAEMC was 1.4 percentage points lower than in the pre-emerging economies of Sub-Saharan Africa. The comparison reveals an even larger gap if Equatorial Guinea is excluded and only the other five CAEMC countries are considered, suggesting that the convergence was mainly due to the oil sector (FMI, 2015).

\section{Governance and Growth in the Economic Literature}

Analyzing the effects of governance on the growth of an economy inevitably means examining the impact of governance indicators on the growth of the economies of the Central Africa Economic and Monetary Community (CAEMC). This economic literature presents the theoretical and empirical literatures.

\subsection{Theoretical Literature}

In the economic literature, theoretical models, including Solow's (1956) and the new growth theory, provide some level of explanation for economic growth within a particular geographic boundary, the understanding of economic growth is still incomplete (Romer, 2001). Moreover, existing growth models do not provide a complete explanation for differences in growth across countries (Romer,

\section{Evolution of real GDP growth}

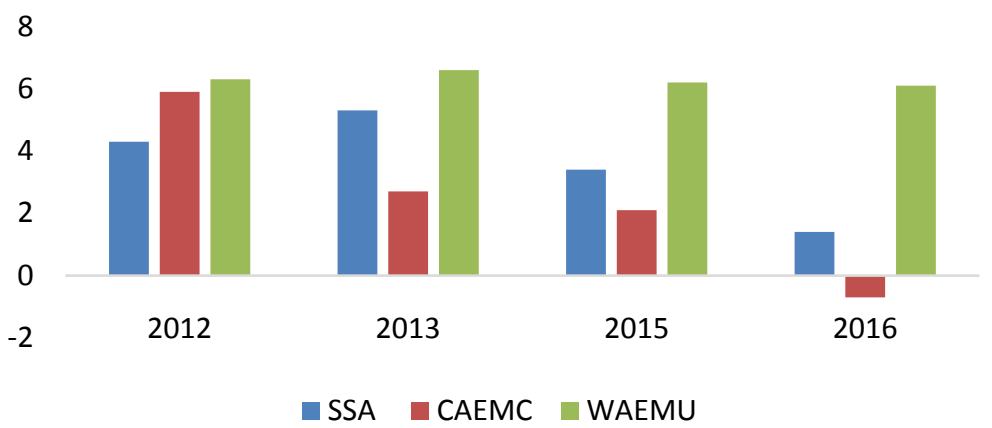

Figure 2. Comparative evolution of real GDP growth. Source: authors, using data from the World Bank (WDI, 2018). 
2001). Economists have turned to deep-seated variables, in particular institutional variables, in an attempt to justify the output gaps between countries that are not explained by economic variables alone. For example, Barro (1990) focuses on democracy; Clague, Keefer, Knack, and Olson (1996) emphasize the importance of respect for property rights; Alesina and Perotti (1996) emphasize the need to take into account a country's political instability; and Rodrik (1997) supports the idea that good governance is a necessary condition for improving economic performance.

The New Institutional Economics (NIE) shows that effective institutions can make a difference in the success of market reforms and even argues that institutions are one of the determinants of long-term economic growth (Mauro, 1995; Isham, Kaufmann, \& Pritchett, 1997; Gray \& Kaufmann, 1998). North (1990) and Rosenberg and Birdzell Jr. (1986) point out that institutions are a priori in interaction with growth. Sustained growth may require adequate institutions, but it in turn provides the resources to build them. Increased economic activity is always accompanied by better institutions.

Kurzman et al. (2002), who studies 106 countries over the period from 1951 to 1980 , concludes that a democratic regime does not significantly impede economic growth, and under many circumstances, stimulates it slightly, notably through investment and public spending. Grier and Tullock (1989), applying the ordinary least squares method in cross-section of time series over a period from 1961 to 1980, conducted an empirical analysis of cross-country economic growth based on data from 113 countries. They find that political stability is positively correlated with economic growth.

Atangana (2013) proves, through GMM, that corruption can trigger economic growth in resource-rich countries that apply democratic principles. Leite et al. (2019) who reveals that corruption has a positive effect on growth supported this idea.

Jalilian et al. (2007) explore the role of regulation in economic outcomes using the fixed effect method. Their results confirm that "good" regulation is associated with higher economic growth, which in turn is conducive to international business expansion. Similarly, Rigobon and Rodrick (2004), and Butkiewicz and Yanikkaya (2004) point to a positive relationship between the rule of law and growth.

In contrast, classical economists have criticized the role of the state. They state that the behavior of the state can slow down growth. Buchanan and Tullock (1962) point out that the state does not act in the general interest but in the individual interest. Politicians seek to maximize their chances of being elected or re-elected, whereas civil servants maximize a utility function (social ascension, increased income, responsibilities). The State would then be only the expression of a coalition of private interests (lobbies), corporate interests or an instrument that would facilitate the promotion of politicians. Thus, the lack of transparency, which informs whether the government's intentions are truly accepted by civil society, can be a brake on growth. 
According to Krueger (1974), various forms of clientelism, nepotism or corruption characterize administrative systems in developing countries. State intervention offers opportunities for rent through employment and legislation. Individuals and pressure groups will have an incentive to invest resources in rent seeking and privilege rather than in increasing production. Politicians will offer rents in exchange for monetary remuneration and/or political support. This rent seeking wastes resources, and is a factor in political violence for rent seeking. He pointed out that corruption hinders economic growth through the waste of resources and factors of political violence.

Niskanen (1971) is based on an extreme vision of the bureaucrat who, taking advantage of lax public control procedures, is considered to have a monopoly, both in terms of the products or services offered and in terms of information. This model leads to the conclusion that there is bureaucratic overproduction and, under certain conditions of demand, unproductive expenditure. For him, the incompetence of bureaucrats, which leads to unproductive overproduction and unproductive expenditure demands, reduces economic performance.

Moreover, Stigler (1971) describes how interest groups and political actors will use the means of regulation and the coercive power of states to steer laws and rules in directions that favour them. The problem is thus the following: the regulatory authority, being subject to the influence of pressure groups, is no longer the guarantor of the general interest. Stigler (1971) has shown that the rule of law can slow down growth through non-compliance with rules and laws.

The synthesis of these theories builds on the reality that maintaining a sustainable level of economic growth in the medium and long term requires a qualitative change in governance structures and institutions, as well as in the behavior of actors.

\subsection{Empirical Literature}

In the empirical literature, the studies on the relationship between economic growth and governance are divided into two axes. Those classified in the first axis focus on a field that prioritizes the positive impact of governance on economic growth. Thus, Ouhirra and Sabri (2019) examine a sample of 04 countries namely: Morocco, Algeria, Tunisia and Turkey by the fixed effect method. The results show that a positive and significant correlation exists between democracy and economic growth. Similarly, Acemoglu et al. (2015), by applying the generalized method of moments (GMM), confirm the existence of a significant and positive relationship between growth and democracy. They conclude that democracy stimulates growth through several channels including: greater economic reforms, investment in primary education and health, higher taxation and public goods supply, and low social unrest. In the same perspective, Doucouliagos and Ulubasoglu (2008) synthesize more than 400 estimates from 84 studies by fixed- and random-effects meta-regression models and show the real positive but indirect impact of democracy on economic growth, the stimulation of the 
growth rate is due to a higher level of income, human capital, economic freedom and less political instability.

In contrast, the second axis lists the work where the impact of governance on economic growth is negative. We have the work of Aisen and Veiga (2013), who analyze a sample of 169 countries during the period 1960-2004 using the GMM method and find that authoritarian systems constrain growth by reducing physical and human capital accumulation.

Aisen and Veiga (2013), analyzed a sample 169 countries during the period from 1960 to 2004 using the GMM estimator and find that political instability negatively affects growth by reducing productivity growth rates and to the lesser extent, physical and human capital accumulation. Pere (2015) finds that political stability has no statistically significant effect on economic growth.

Omrane (2016) studies the effect of corruption on economic growth in Algeria over the period from 1995 to 2012 using OLS estimation. He concludes that corruption negatively and significantly affects growth through investment and public spending. In the same framework, Mo (2001) analyzed the impact of corruption on economic growth from 1970 to 1985 on 54 countries using OLS, and found that corruption negatively affects growth via political instability. Similarly, a systematic review of available data on the impact of corruption on economic growth by Ugur and Dasgupta (2011) confirms that corruption has a direct negative effect on growth in low-income countries. According to this analysis, corruption also has indirect effects through investment, human capital, public finance, and public spending.

Gani (2011) finds by applying the GMM method that regulatory quality and rule of law have a negative but insignificant effect on economic growth. Similarly, Etsiba et al. (2018) demonstrated using a fixed-effect model that institutional governance understood by the rule of law has a negative influence on economic growth in CAEMC countries through the lobbies maintained by most of the senior executives of the states in this subregion. The empirical literature, through the narrow indicators of governance, shows that governance has a strong influence on economic growth.

\section{Methodological Approach and Results}

This section presents, first, the methodological approach and, second, the results.

\subsection{Methodological Approach}

This sub-section presents, first, the methodological approach and, second, the presentation of variables and estimation procedure.

\subsubsection{Methodological Approach}

To analyze the effects of governance on the growth of CAEMC economies, the methodology borrowed from Solow (1956) and Mankiw et al. (1992). This model, which is based on an exogenous view of growth, takes into account other factors such as human capital in the so-called augmented production function. 


$$
\begin{gathered}
Y=A F(L ; K)=A L^{\alpha} K^{\beta} \\
Y=K_{i}^{\alpha} H_{i}^{\beta}\left(A_{i} L_{i}\right)^{1-\alpha}
\end{gathered}
$$

where $A_{i}$ denotes the technical progress that increases labor, the aggregate $H_{i}$, the human capital stock and $L_{i}$ the gross labor stock. According to this model, investment in human capital increases worker productivity and the growth of a nation, all other things being equal.

By dividing the expression $Y$ by $L$, we find a more simplified expression as follows:

$$
\frac{Y_{i}}{L_{i}}=y_{i}=A_{i} k_{i}^{\alpha} h_{i}^{\beta} \text { with } k_{i}=K_{i} / A_{i} L_{i} ; h_{i}=H_{i} / A_{i} L_{i}
$$

After linearization by the logarithm, our model becomes

$$
\ln y_{i}=\ln A_{i}+\alpha \ln k_{i}+\beta \ln h_{i}
$$

The share of investment in GDP represents physical capital per capita (k). It is taken as the share of GFCF in GDP, while primary or secondary school enrollment is used as a proxy for human capital ( $h$ ).

The model specified in the analysis of the relationship between governance and growth is inspired by the work of Pellegrini and Gerlagh (2004) and is as follows:

$$
Y_{i t}=\beta_{0}+\beta_{2} \mathrm{GOV}_{i t}+\beta_{3} \mathrm{FDI}_{i t}+\beta_{4} \log \mathrm{GFCF}_{i t}+\beta_{5} \log L_{i t}+e_{i t}
$$

In order to avoid the endogeneity problem of the variables and to control for individual and time specific effects, we believe that the use of Arellano and Bond's (1991) estimator of taking for each period the first difference in the equation to be estimated is relevant to eliminate country specific effects and to instrument for lagged explanatory variables. The lagged variable in our model is " $Y$ " so the model will be rewritten as follows:

$$
Y_{i t}=\beta_{0}+\beta_{1} Y_{i t-1}+\beta_{2} \mathrm{GOV}_{i t}+\beta_{3} \mathrm{FDI}_{i t}+\beta_{4} \log \mathrm{GFCF}_{i t}+\beta_{5} \log L_{i t}+e_{i t}
$$

where $Y_{i t}$ represents the logarithm of GDP; $Y_{i t-1}$, the logarithm of lagged GDP; $\mathrm{GOV}_{i t}$ the various governance variables (corruption, rule of law, political instability and violence, voice and accountability, regulatory quality, and government effectiveness); $\mathrm{FDI}_{i t}$ the foreign direct investment; $\log \mathrm{GFCF}_{i t}$ the domestic investment; $\log L_{i t}$ the labor force; $e_{i t}$ the error term; $i$ is the country index and $t$ is the time index. The data are taken from the Worldwide Governance Indicators (WGI, 2016) and World Development Indicators (WDI, 2018) databases of the World Bank over the period from 2002 to 2015 . The choice of this period is dictated by the availability of data, particularly for governance indicators.

\subsubsection{Presentation of Variables and Estimation Procedure}

This point discusses, first, the presentation of the variables and the descriptive analysis and, second, the estimation procedure.

1) Presentation and descriptive analysis of the variables

The different variables used in this paper are presented in Table 1. 
Table 1. Presentation of the variables.

\begin{tabular}{cc}
\hline Description of variables & Variable \\
\hline Gross Domestic Product & $\mathrm{GDP}$ \\
Voice and accountability & $\mathrm{Va}$ \\
Government effectiveness & $\mathrm{Eg}$ \\
Political stability & $\mathrm{Ps}$ \\
Regulatory quality & $\mathrm{Rq}$ \\
Rule of law & $\mathrm{Rl}$ \\
Corruption control & $\mathrm{Cc}$ \\
Foreign direct investment & $\mathrm{FDI}$ \\
Gross fixed capital formation & $\mathrm{GFCF}$ \\
Labor force & $\mathrm{L}$ \\
\hline
\end{tabular}

\section{2) Descriptive analysis of variables}

The descriptive analysis of the variables shows that, on the one hand, the series of: voice and accountability; rule of law; regulatory quality; government effectiveness; and corruption give a high concentration (low standard deviations) around the mean value and, on the other hand, the series of political instability; gross fixed capital formation; foreign direct investment; labor force; and GDP show a low concentration (large standard deviations) around the mean value (see Table A1, in Appendix).

\subsubsection{Estimation Procedure}

In this work, the estimation procedure is based on the following points 1) verification of the stationarity of the variables, 2) cointegration test to verify the existence of a long term relationship between the series and finally 3) estimation of the panel data model.

\section{Stationarity}

To determine the order of integration of our series, we used the first generation test of Levin and Lin (1993) and Levin et al. (2002), whose specificity lies in the consideration of the homogeneity of the autoregressive root. Moreover, this test was developed from the time series unit root tests of Dickey and Fuller (1979). For this purpose, Levin and Lin (1993) and Levin et al. (2002) used the following three models to test the unit root according to the form that the deterministic component takes:

Model 1: $\Delta y_{i, t}=\rho y_{i, t-1}+\varepsilon_{i, t}$

Model 2: $\Delta y_{i, t}=\alpha_{i}+\rho y_{i, t-1}+\varepsilon_{i, t}$

Model 3: $\Delta y_{i, t}=\alpha_{i}+\beta_{i, t}+\rho y_{i, t-1}+\varepsilon_{i, t}$

Where $i=1, \cdots, N$ and $i=1, \cdots, T$ and where the error terms $\varepsilon_{i, t}$ are independently distributed across individuals, $i$ and follow a stationary and invertible ARMA process admitting an $A R(\infty)$ representation of the type:

$$
\varepsilon_{i, t}=\sum_{k=1}^{\infty} \theta_{i, t} \varepsilon_{i, t-k}+\mu_{i, t}
$$


The processes $\mu_{i, t}$ for $i=1, \cdots, N$ are i.i.d. $\left(0, \sigma_{\mu, i}^{2}\right)$.

Using these three models, Levin and Lin propose to test the following hypotheses:

$$
\begin{aligned}
& \text { Model 1: }\left\{\begin{array}{l}
H_{0}: \rho=0 \\
H_{1}: \rho<0
\end{array}\right. \\
& \text { Model 2: }\left\{\begin{array}{l}
\mathrm{H}_{0}: \rho=0 \text { et } \alpha_{i}=0, \forall i=1, \cdots, N \\
\mathrm{H}_{1}: \rho<0 \text { et } \alpha_{i} \in R, \forall i=1, \cdots, N
\end{array}\right. \\
& \text { Model 3: }\left\{\begin{array}{l}
\mathrm{H}_{0}: \rho=0 \text { et } \beta_{i}=0, \forall i=1, \cdots, N \\
\mathrm{H}_{1}: \rho<0 \text { et } \beta_{i} \in R, \forall i=1, \cdots, N
\end{array}\right.
\end{aligned}
$$

Where the null hypotheses in models (2) and (3) are joint hypotheses that visibly fit the structure of the two joint tests found in the Dickey-Fuller (1981) unit root test for time series.

\section{Cointegration tests}

The literature on panel cointegration tests has developed around two main tests, namely the Pedroni (1999) and Kao (1999) tests, which are the most widely used in empirical work and make it possible to avoid the problem of spurious regression when the series are non-stationary and not cointegrated.

Note that these two tests have identical null hypotheses and all assume the absence of inter-individual dynamics and thus verify the existence of an intra-individual cointegration relationship. To confirm the hypothesis of the existence of a cointegrating relationship, Pedroni proposed seven statistical tests. Among these tests, three are based on the between dimension and four on the within dimension. While for the tests that are based on the between dimension the alternative hypothesis is: $H_{1}: \theta_{i}<1$ for all $i$, under the within dimension, it takes the following form instead: $H_{1}: \theta_{i}=\theta<1$ for all $i$. Kao (1999) devised several ADF-type tests of stationarity of the residuals of the cointegrating relationship. In these tests, the cointegrating vectors are considered homogeneous across individuals, and the (null) hypothesis shows the absence of cointegration.

To estimate the economic model we specified above, traditional econometric methods such as OLS, fixed effect and quasi-generalized least squares do not allow us to obtain efficient estimates. We use the generalized panel method of moments (GMM) proposed by Arellano and Bond (1991), and later developed by Arellano and Bover (1995) and Blundell and Bond (1998). According to the advocates of this method, it provides solutions to the problems of simultaneity bias, reverse causality and possible omitted variables. The implementation of the empirical approach led to the results presented below.

\subsection{Results}

This sub section presents and interprets the results.

\subsubsection{Presentation of the Results}

This point presents the results of the stationarity test, the cointegration test and the model estimations.

1) Results of the stationarity test 
The results obtained after applying the unit root test of Levin, Lin and Chu (2002) and Im, Pesaran and Shin (2003) on the variables selected above show that our variables are stationary in level, first difference and second difference (see Table A2 in Appendix).

\section{2) Results of the cointegration test}

The results of the Pedroni and Kao cointegration tests presented in Table A4 of Appendix, reveal at least one cointegrating relationship on the seven (7) equations of the Pedroni and Kao tests. In conclusion, the alternative hypothesis of the existence of a cointegrating relationship in the medium and long term between economic growth and governance is accepted at the $1 \%$ and $5 \%$ threshold. (see Table A3 in Appendix).

\section{3) Results of the model estimations.}

The results of the estimates, after treatment by the generalized method of moments, are presented in Table 2 and Table 3.

Table 2. Results of the estimation without institutional variable.

\begin{tabular}{cccc}
\hline Endogenous Variable: LogGDP & & \\
\hline Exogenous Variable & Coefficient & Std. Dev & $p>|z|$ \\
\hline L1 & 0.888 & 0.249 & $0.000^{* * *}$ \\
FDI & -0.048 & 0.016 & $0.004^{* *}$ \\
Log GFCF & 0.191 & 0.325 & $0.000^{* * *}$ \\
Log L & -0.610 & 0.247 & $0.014^{* *}$ \\
Cons & 3.540 & 0.760 & $0.000^{* * *}$
\end{tabular}

Source: authors, from stata 14 .

Table 3. Model with institutional variable.

\begin{tabular}{cccc}
\hline Endogenous variable: LogGDP & & & \\
\hline Variables & Coefficient & Std. Dev & $p>|z|$ \\
L1 & 0.889 & 0.277 & 0.000 \\
FDI & -0.039 & 0.016 & 0.016 \\
Log GFCF & 0.138 & 0.040 & 0.001 \\
Log L & -0.043 & 0.039 & 0.279 \\
Corruption & -0.213 & 0.082 & 0.009 \\
Government effectiveness & -0.120 & 0.066 & 0.068 \\
Political instability & -0.030 & 0.032 & 0.342 \\
Regulatory quality. & 0.177 & 0.084 & 0.035 \\
Rule of law & 0.620 & 0.093 & 0.507
\end{tabular}

Source authors, from stata 14. 
Model 1: Model without institutional variables

This model without institutional variables allows us to see the behavior of the GDP of CAEMC countries in the absence of institutional variables. The analysis of the overall quality of the model shows us that: the lagged GDP has a positive coefficient. Its probability being less than $1 \%$, this variable allows us to validate the model. The Wald statistic is 1973.15 with a probability of less than $1 \%$. This means that the variables used in this model do explain the endogenous variable. These results show us that the model used is globally significant and of good quality. We can say that the application of the dynamic model approach is good because its coefficient is positive and significant. There is therefore a dynamic relationship between the variables over time.

After some preliminary tests, on the presence or not of autocorrelation and heteroscedasticity of the residuals, we notice that the results of the heteroscedasticity test show a probability associated with the Chi2 statistic higher than $5 \%$ so we do not accept the hypothesis of heteroscedasticity of the residuals. The Arellano-Bond test on the autocorrelation of the errors taken with a single lag gives probabilities associated with the coefficients greater than $5 \%$, which allows us to accept the hypothesis of no autocorrelation of the errors. The estimation results show that: Foreign direct investment is statistically significant. Its coefficient is negative. This means that with an increase of one unit in foreign direct investment, there is a reduction in the GDP of CAEMC countries of 0.048 units. The two variables move in opposite directions. Gross fixed capital formation is statistically significant. Its coefficient is positive.

This means that with a $1 \%$ increase in Gross Fixed Capital Formation (GFDF), the GDP of CAEMC countries increases by $0.191 \%$. The two variables move in the same direction. Labor force is statistically significant. Its coefficient is negative. This shows that with a $1 \%$ increase in the labor force, there is a $0.61 \%$ reduction in the GDP of CAEMC countries. The two variables move in opposite directions.

Model 2: Model with institutional variable

After introducing the institutional variables, the analysis of the global quality of the model shows us that: the Wald statistic is 1847.36 and its associated probability is less than $5 \%(0.000)$. The model is globally significant and of good quality. We notice that the coefficient associated with the endogenous variable, taken with a delay, is significant and positive. This allows us to validate the dynamic panel model. Some preliminary tests on the presence or not of heteroscedasticity of the residuals and autocorrelation of the errors have been performed. The Arellano-Bond test on autocorrelation shows that the probabilities associated with the coefficients are all greater than $5 \%$. Thus, the hypothesis of no autocorrelation of errors is approved, i.e., the variables are independent of each other in our model. The results of the heteroscedasticity test show that the probability associated with the Chi 2 statistic is greater than $5 \%$. Therefore, there is no heteroscedasticity. 
The results of the estimation of "civic voice and responsibility" are statistically significant and positive. Both variables move in the same direction. An increase of one unit in "citizen voice and democratic accountability" leads to an increase of 0.20 in the GDP of CAEMC countries.

The quality of regulation is statistically significant and positive. Both variables move in the same direction, with a one-unit increase in regulatory quality leading to a 0.177 increase in GDP for CAEMC countries.

Corruption is statistically significant and negative. The two variables move in opposite directions. A one-unit increase in corruption leads to a 0.213 reduction in GDP for CAEMC countries. The two variables move in opposite directions. Gross fixed capital formation is statistically significant and positive. Its $1 \%$ increase leads to a 0.138 improvement in the GDP of CAEMC countries. The two variables move in the same direction. Net foreign direct investment is statistically significant and negative. An increase of one unit of foreign direct investment leads to a decrease of 0.039 in the GDP of CAEMC countries. The two variables move in opposite directions.

\subsubsection{Interpretation of Results}

Taking into account the institutional indicators, the estimation results allow us to draw two lessons:

\section{> Corruption: Hindrance to the Growth of CAEMC Economies.}

This result validates the work of Mo (2001) who states that corruption is an obstacle on the economies of developing countries. Indeed, corruption is a global scourge that affects developing countries. This finding shows that CAEMC countries suffer from corruption problems. The absence of effective measures compromises the efforts of member countries to establish good governance and reduce poverty. Its multiple harms (waste of financial resources, reduced growth, increased uncertainty, creation of an environment of insecurity, etc.) undermine the social and political stability of member countries. Corruption generally indicates a structural weakness of national institutions and an inability of public authorities to exercise rigorous control over the actions of public officials and economic operators.

\section{Democracy and Regulatory Quality: Growth Factors for CAEMC Econ-} omies.

This result validates the work of Acemoglu et al. (2015) and contradicts that of Gani (2011), which states, respectively, that democracy positively influences the growth of CAEMC economies and that regulatory quality has a negative effect on the growth of CAEMC economies. Based on the premise that a credible and effective political system contributes to sustainable and sustained wealth creation, the low growth rates of CAEMC economies are justified by the existence of weak institutions and truly undemocratic powers because the effectiveness of institutions depends on both policies and regulatory instruments and the quality of governance.

In sum, this study shows that corruption, bureaucratic quality and political 
instability negatively influence the growth of CAEMC countries' economies. In contrast, regulatory quality, rule of law, and citizen voice and accountability have a positive impact on the growth of CAEMC economies.

\section{Conclusion and Policy Implications}

The objective of this study was to highlight the effects of governance indicators on economic growth in CAEMC economies. The analysis conducted using panel data econometrics, in accordance with the generalized method of moments, over a period from 2002 to 2015, showed that corruption, bureaucratic quality, and political instability have a negative impact on the growth of CAEMC countries' economies. On the other hand, regulatory quality, rule of law, and citizen voice and accountability have a positive impact on the growth of CAEMC economies. Thus, we argue that of the six indicators of Kaufmann et al. (1999), three (voice and accountability, regulatory quality, and corruption) have a significant influence on the growth of CAEMC economies. The last indicator has a negative influence on economic growth. The hypothesis defended in this study is therefore verified.

In order to emerge from the accommodation of underdevelopment, profound institutional changes are necessary for CAEMC countries. The results suggest that the authorities should implement strategies that would help to fight corruption and political instability. This would also improve the effectiveness of government actions and the quality of the regulatory framework. Credible governance will help to improve the level of growth of CAEMC economies.

\section{Conflicts of Interest}

The authors declare no conflicts of interest regarding the publication of this paper.

\section{References}

Acemoglu, D., Naidu, S., Restrepo, P., \& Robinson, J. A. \{(2015). Democracy, Redistribution, and Inequality. Handbook of Income Distribution, 2, 1885-1966. https://doi.org/10.1016/B978-0-444-59429-7.00022-4

Acemoglu, D., Naidu, Z., Restrepo, P., \& Robinson, J. (2019). Democracy Does Cause Growth. Journal of Political Economy, 127, 47-100. https://doi.org/10.1086/700936

ADB (African Development Bank) (1999). Bank Group Policy on Good Governance. https://www.afdb.org/fileadmin/uploads/afdb/Documents/Policy-Documents/21-EN-B ank Group Policy on Good Governance.pdf

Aisen, A., \& Veiga, F. (2013). How Does Political Instability Affect Economic Growth? European Journal of Political Economy, 29, 151-167. https://doi.org/10.1016/j.ejpoleco.2012.11.001

Alesina, A., \& Perotti, R. (1996). Income Distribution, Political Instability and Investment. European Economic Review, 40, 1203-1228. https://doi.org/10.1016/0014-2921(95)00030-5

Arellano, M., \& Bond, S. (1991). Some Tests of Specification for Panel Data: Monte Carlo 
Evidence and an Application to Employment Equations. Review of Economics Studies, 58, 277-297. https://doi.org/10.1016/0014-2921(95)00030-5

Arellano, M., \& Bover, O. (1995). Another Look at the Instrumental Variable Estimation of Error Components Models. Journal of Econometrics, 68, 29-52. https://doi.org/10.1016/0014-2921(95)00030-5

Atangana, H. (2013). Gouvernance et croissance économique. African Development Review, 25, 130-147. https://doi.org/10.1111/j.1467-8268.2013.12020.x

Baliamoune-Lutz, M., \& Ndikumana, L. (2009). Corruption et Croissancedans les Pays Africains: le canal de l'Investissement. Economica, 17, 433-448.

Bangui, T. (2015). La mal-gouvernance: Malédiction des ressources naturelles ou déficit de leadership? Etudes Africaines, 7-20.

Barro, R. (1990). Government Spending in Simple Model of Endogenous Growth. Journal of Political Economy, 98, 103-125. https://doi.org/10.1086/261726

Barro, R. (1996). Democracy and Growth. Journal of Economic Growth, 1, 1-27. https://doi.org/10.1086/261726

Blundell, R., \& Bond, S. (1998). Initial Conditions and Moment Restrictions in Dynamic Panel Data Models. Journal of Econometrics, 87, 115-143.

https://doi.org/10.1016/S0304-4076(98)00009-8

Bodjongo, M. (2012). Infrastructures institutionnelles et développement financier en zone CEMAC (pp. 1-19). MPRA Paper n 37824, Posted on 9 April 2012.

Buchanan, J., \& Tullock, G. (1962). The Calculus of Consent: Logical Foundations of Constitutional Democracy. Ann Arbor, MI: University of Michigan Press.

Butkiewicz, J., \& Yanikkaya, H. (2004). Sociopolitical Instability and Long Run Economic Growth. Working Paper n 04-04, Newark, DE: University of Delaware, Department of Economics.

Clague, C., Keefer, P., Knack, S., \& Olson, M. (1996). Property and Contract Rights in Autocracies and Democracies. Journal of Economic Growth, 1, 243-276. https://doi.org/10.1007/BF00138864

Dickey, D. A., \& Fuller, W. A. (1979). Distribution of the Estimators for Autoregressive Time Series with a Unit Rootî. Journal of the American Statistical Association, 74, 417-431. https://doi.org/10.1080/01621459.1979.10482531

Doucouliagos, H., \& Ulubasoglu, A. (2008). Democracy and Economic Growth: A Meta-Analysis. American Journal of Political Science, 52, 61-83. https://doi.org/10.1111/j.1540-5907.2007.00299.x

Etsiba, S. N., Ndombi, F., \& Bozongo, J. (2018). Effets de la gouvernance institutionnelle sur la croissance économique dans la CEMAC. Annales de l'Université Marien Ngouabi, 18, 138-148.

FMI (Fonds Monétaire International) (2015). Perspectives de l'économie mondiale: Croissance inégale-Facteurs à court et long terme. Washington DC: Fonds Monétaire International.

FMI (Fonds Monétaire International) (2017). Rapport des services du FMI sur les politiques communes à l'appui des programmes de réformes des pays membres de la $C E M A C$. Washington DC: Fonds Monétaire International.

Gani, A. (2011). Governance and Growth in Developing Countries. Journal of Economic, 45, 19-40. https://doi.org/10.2753/JEI0021-3624450102

Gray, C., \& Kaufmann, D. (1998). Corruption et développement. Finances et développe- 
ment, 7-10.

Grier, K., \& Tullock, G. (1989). An Empirical Analysis of Cross National Economic Growth. Journal of Monetary Economics, 24, 259-276. https://doi.org/10.1016/0304-3932(89)90006-8

Hall, E., \& Jones, C. (1999). Why Do Some Countries Produce So Much More Output per Worker than Others. Quarterly Journal of Economics, 114, 83-116. https://doi.org/10.1162/003355399555954

Im, K. S., Pesaran, M. H., \& Shin, Y. (2003). Testing for Unit Roots in Heterogeneous Panel. Journal of Econometrics, 115, 53-74. https://doi.org/10.1016/S0304-4076(03)00092-7

Isham, J., Kaufmann, D., \& Pritchett, L. (1997). Civil Liberties, Democracy and the Performance of Government Project. The World Bank Economic Review, 11, 219-242. https://doi.org/10.1093/wber/11.2.219

Jalilian, H., Kirkpatrick, C., \& Parker, D. (2007). The Impact of Regulation on Economic Growth in Developing Countries: A Cross-Country Analysis. World Development, 35, 87-103. https://doi.org/10.1016/j.worlddev.2006.09.005

Kao, C. (1999), Spurious Regression and Residual-Based Tests for Cointegration in Panel Data. Journal of Econometrics, 90, 1-44. https://doi.org/10.1016/S0304-4076(98)00023-2

Kaufmann, D., Kraay, A., \& Mastruzzi, M. (2004). Government Matters III: Governance Indicators 1996-2002. Washington DC: World Bank Economic Review. https://doi.org/10.1596/1813-9450-3106

Kaufmann, D., Kraay, A., \& Zoido-Lobaton, P. (1999). Aggregating Governance Indicators. World Bank Policy Research, Working Paper, 2196. Washington DC: World Bank Institute.

Knack, S., \& Keefer, P. (1997). Does Social Capital Have an Economic Payoff? A Cross Country Investigation. Quarterly Journal of Economics, 112, 1251-1258. https://doi.org/10.1162/003355300555475

Krueger, A. (1974). The Political Economy of Rent Seeking Society. American Economic Review, 64, 291-303.

Kurzman, C., Werum, R., \& Burkhart, R. E. (2002). The Democracy's Effect on Economic Growth: A Pooled Time Series Analysis. Studies in Comparatives International Development, 1, 3-33. https://doi.org/10.1007/BF02686336

Kuznets, S. (1973). Modern Economic Growth: Findings and Reflections. The American Economic Review, 63, 247-258.

Leite, N., Carvalho Lucio, F., \& Ferreira, R. (2019). Long-Term Effects of Corruption Control and Economic Freedom on Economic Growth. Theoretical Economics Letters, 9, 2965-2974. https://doi.org/10.4236/tel.2019.98183

Levin, A., \& Lin, C. F. (1993). Unit Root Tests in Panel Data: New Results. Discussion Paper 92-93. San Diego: University of California.

Levin, A., Lin, C. F., \& Chu, C. S. J. (2002). iUnit Root Test in Panel Data: Asymptotic and Finite Sample Properties. Journal of Econometrics, 108, 1-24.

https://doi.org/10.1016/S0304-4076(01)00098-7

Lucas, R. (1988). On the Mechanics of Economic Development. Journal of Monetary Economics, 22, 3-42. https://doi.org/10.1016/0304-3932(88)90168-7

Mankiw, G., Weil, D., \& Romer, D. (1992). A Contribution to the Empirics of Economic Growth. The Quarterly Journal of Economics, 107, 407-437. 
https://doi.org/10.2307/2118477

Mauro, P. (1995). Corruption and Growth. Quarterly Journal of Economics, 110, 681-712. https://doi.org/10.2307/2946696

Mo, P. H. (2001). Coruption and Economic Growth. Journal of Comparative Economics, 29, 66-79. https://doi.org/10.1006/jcec.2000.1703

Niskanen, W. A. (1971). Bureaucracy and Representative Government (Vol. 68). Chicago, IL and New York: Aldine-Atherton, Inc.

North, D. (1990). Institutions, Institutional Change and Economic Performance. Cambridge: Cambridge University Press. https://doi.org/10.1017/CBO9780511808678

Omrane, B. (2016). Corruption et Croissance Économique: une Approche Économétrique sur les Données de l'Algérie. European Scientific Journal, 12, 1857-7431. https://doi.org/10.19044/esj.2016.v12n7p434

Ouhirra, I., \& Sabri, H. (2019). Democratie et croissance économique: Une analyse empirique. Kénitra: Université Ibn Tofail.

Pedroni, P. (1999). Critical Values for Cointegration Tests in Heterogenous Panels with Multiple Regressors. Oxford Bulletin of Economics and Statistics, S1, 61, 653-670. https://doi.org/10.1111/1468-0084.61.s1.14

Pellegrini, L., \& Gerlagh, R. (2004). Corruption's Effect on Growth and Its Transmission Channels. Kyklos, 57, 429-456. https://doi.org/10.1111/j.0023-5962.2004.00261.x

Pere, E. (2015). The Impact of Good Governance in Economic Development of Western Balkan Countries. European Journal of Government and Economics, 14, 25-45. https://doi.org/10.17979/ejge.2015.4.1.4305

Rigobon, R., \& Rodrik, D. (2004). Rule of Law, Democracy, Openness and Income: Estimating the Inter Relationship. NBER Working Paper No. 10750, Cambridge, MA: National Bureau of Economic Research. https://doi.org/10.17979/ejge.2015.4.1.4305

Rodrik, D. (1997). TFPG Controversies, Institutions and Economic Performance in East Asia. NBER Working Paper No. 5914, Cambridge, MA: National Bureau of Economic Research. https://doi.org/10.3386/w5914

Romer, D. (2001). Advanced Macroeconomics, International Edition. New York: McGraw-Hill.

Rosenberg, N., \& Birdzell Jr., L. E. (1986). How the West Grew Rich: The Economic Transformation of the Industrial World (pp. xii, 353). New York: Basic Books.

Solow, R. (1956). A Contribution to the Theory of Economic Growth. Quarterly Journal of Economics, 70, 65-94. https://doi.org/10.2307/1884513

Stigler, G. (1971). The Theory of Economic Regulation. The Bell Journal of Economics and Management, 2, 3-21. https://doi.org/10.2307/3003160

Stigler, G. J. (1975). The Citizen and the State: Essays on Regulation. Chicago: University of Chicago Press.

Ugur, M., \& Dasputa, N. (2011). Corruption and Economic Growth: A Meta Analysis of the Evidence on Low Income Countries and Beyond. MPRA Working Paper No. 31226. https://mpra.ub.uni-muenchen.de/31226

WDI (World Development Indicators) (2018). Database World Bank. https://databank.worldbank.org/source/world-development-indicators

WGI (Worldwide Governance Indicators) (2016). Database Indicators Governance. https://datacatalog.worldbank.org/dataset/worldwide-governance-indicators. 


\section{Appendix}

Table A1. Descriptive analysis.

\begin{tabular}{cccccc}
\hline Variable & average & Std. Dev & Minimum & Maximum & Observation \\
\hline GDP & $4.20 \mathrm{E}+12$ & $2.99 \mathrm{E}+12$ & $5.63 \mathrm{E}+11$ & $1.18 \mathrm{E}+13$ & $\mathrm{~N}=84$ \\
Ide & 6.490129 & 8.981771 & 4.852284 & 46.4937 & $\mathrm{~N}=84$ \\
Fbcf & 26.29173 & 15.49599 & 6.404792 & 114.7254 & $\mathrm{~N}=84$ \\
Popact & 2741373 & 2629222 & 283748 & 916788 & $\mathrm{~N}=84$ \\
$\mathrm{Cc}$ & -1.20481 & 0.3249279 & -1.83609 & -0.4190092 & $\mathrm{~N}=84$ \\
$\mathrm{Eg}$ & -1.210397 & 0.3554516 & -1.791606 & -0.394153 & $\mathrm{~N}=84$ \\
$\mathrm{Sp}$ & -0.4665313 & 0.6945902 & -2.086425 & 0.3865264 & $\mathrm{~N}=84$ \\
$\mathrm{Rq}$ & -1.060978 & 0.3328032 & -1.490816 & -0.164162 & $\mathrm{~N}=84$ \\
$\mathrm{Rl}$ & -1.134028 & 0.3202666 & -1.721163 & -0.2055656 & $\mathrm{~N}=84$ \\
Go to & -1.219221 & 0.3343466 & -2.002323 & -0.5550501 & $\mathrm{~N}=84$ \\
\hline
\end{tabular}

Source: Authors, from stata 14.

Table A2. Result of the stationarity test.

\begin{tabular}{|c|c|c|c|c|c|c|}
\hline \multicolumn{4}{|c|}{ LLC } & \multicolumn{3}{|c|}{ IPS } \\
\hline Variables & With Trend & With Constant & No constant & With Trend & With Trend & Decision \\
\hline $\mathrm{Cc}$ & $-5.08244^{\star * *}$ & $-4.11829^{\star \star \star}$ & 0.41559 & $-2.98932^{* * *}$ & $-2.41417^{\star *}$ & $\mathrm{I}(0)$ \\
\hline Fbcf & $-5.45003^{\star * *}$ & $-6.65156^{\star * *}$ & $-8.59600^{* * *}$ & $-3.13796^{\star * *}$ & $-3.42222^{* * *}$ & $\mathrm{I}(0)$ \\
\hline $\mathrm{Eg}$ & $-8.58271^{\star * *}$ & $-1.7214^{\star *}$ & 0.49012 & $-6.81131^{\star \star *}$ & -1.36825 & $\mathrm{I}(0)$ \\
\hline Ide & $-3.17300^{* * *}$ & $-3.26317^{\star * *}$ & $-3.13072^{\star * *}$ & $-2.58521^{\star *}$ & $-2.04856^{* *}$ & $\mathrm{I}(0)$ \\
\hline $\mathrm{Sp}$ & $-2.58917^{\star \star}$ & -0.45322 & $-3.29195^{\star * *}$ & $-3.5465^{\star * *}$ & $-3.71901^{\star * *}$ & $\mathrm{I}(0) / \mathrm{I}(1)$ \\
\hline Qr & -1.34365 & $-1.81046^{\star *}$ & 0.38983 & $-3.34908^{\star * *}$ & -1.08426 & $\mathrm{I}(0) / \mathrm{I}(1)$ \\
\hline $\mathrm{Rl}$ & -0.73181 & $-3.09459^{\star *}$ & -1.42030 & $-2.92587^{\star \star}$ & $-2.26835^{\star *}$ & $\mathrm{I}(0) / \mathrm{I}(1)$ \\
\hline Go to & $-4.54152^{\star * *}$ & $-3.69064^{* * *}$ & 0.67671 & $-2.92266^{\star *}$ & $-2.17987^{\star *}$ & $\mathrm{I}(0)$ \\
\hline GDP & -1.61720 & $-3.65175^{\star * *}$ & -0.74851 & $-4.27690^{\star * *}$ & $-2.73947^{\star * *}$ & $\mathrm{I}(1) / \mathrm{I}(2)$ \\
\hline Popact & 66.5460 & 80.7484 & $-2.37867^{\star *}$ & -0.19615 & 3.85631 & $\mathrm{I}(2)$ \\
\hline
\end{tabular}

Source: Author, from Eviews 7. ${ }^{* * *}$ ) significant at the $1 \%$ error level; $\left(^{* *}\right)$ significant at the $5 \%$ error level. $\mathrm{I}(0), \mathrm{I}(1)$ and $\mathrm{I}(2)$ explain the stationarity of the variables, respectively, in level; in first difference and in second difference.

Table A3. Results of Pedroni's cointegration test on the variables of interest.

\begin{tabular}{ccccc}
\hline \multicolumn{4}{c}{ Alternative hypothesis: common Arcoefs: (Within-dimension) } \\
\hline Test statistics & V-stat & Rho-stat & Pp-stat & ADF-stat \\
\hline Value & 5.228701 & 4.079365 & -2.541532 & -0.113941 \\
$P$-value & 0.0000 & 0.9993 & 0.0055 & 0.4546 \\
\hline \multicolumn{5}{c}{ Alternative hypothesis: Individual AR coef (between-dimension) } \\
\hline Value & Group Rho-stat & Group pp-stat & Group ADF stat & \\
$P$-value & 4.172144 & -10.54342 & 0.229204 & \\
\hline
\end{tabular}


Table A4. Kao cointegration test results.

\begin{tabular}{cccc}
\hline \multicolumn{4}{c}{ Newey-West automatic bandwidth selection and Bartlett Kernel } \\
\hline Test statistics & ADF & Residual variance & HAC variance \\
\hline Value & -1.600732 & $1.10 \mathrm{E}+23$ & $1.97 \mathrm{E}+23$ \\
$P$-value & 0.0547 & & \\
\hline
\end{tabular}

